\title{
Economic Effects of Agricultural Biotechnology Research in the Presence of Price-Distorting Policies
}

\author{
Kym Anderson \\ CEPR, and University of Adelaide Adelaide
}

Chantal Nielsen

University of Copenhagen

\begin{abstract}
The economic welfare implications of some countries using new genetically modified varieties in crop production will depend on which countries choose to adopt them and on whether others (notably Western Europe) ban their importation. They also depend on existing (non-GMO-specific) agricultural policies in affected markets. This paper uses a well-received empirical economywide model of the global economy (GTAP) to quantify the effects of selected countries enjoying an assumed degree of productivity growth from adopting GMO maize and soybean. It does so first by leaving existing distortionary policies in place and then assuming agricultural policies in Western Europe are completely liberalised. In both cases we investigate the effects of Western Europe refraining from using GMO technology in its own farm production but without versus with a ban on imports of GM products. The results suggest that (a) such an import ban would have a large adverse effect on economic welfare, particularly in Western Europe itself, and $(b)$ while estimated global economic welfare benefits from the new biotechnology are not greatly reduced by Europe's traditional price-distorting

\footnotetext{
*Corresponding address: Kym Anderson, Development Research Group Mailstop MC3-303 The World Bank 1818H Street NW Washington DC 20433, USA Tel: (+1) 202-473-9081, Fax: (+1) 202-522-1159, Email: kanderson@worldbank.org, Chantal Nielsen, University of Copenhagen, and Danish Research Institute of Food Economics (FOI) 1958 Copenhagen, Denmark Tel: +45 3528 6864, Fax: +45 3528 6800, E-mail: chantal@foi.dk

(C)2004-Center for International Economics, Sejong Institution, All Rights Reserved.
} 
policies, the reductions in technology gains are concentrated in non-European countries.

- JEL Classifications: C68, D58, F13, O3, Q17, Q18

- Key words: GMOs, Benefits of R\&D, Agricultural and trade policies

\section{Introduction}

The post-World War II literature on the economics of agricultural research, while concerned initially with the investments being made in the middle half of the twentieth century in the US, was followed by a second generation of studies that was stimulated from the 1960s by the Green Revolution of dwarf cereal varieties targeted at boosting yields in developing countries. We are now entering a third generation, which is drawing on the new biotechnology revolution to generate crop varieties that in some cases involve genetically modified organisms (GMOs). While that began to take hold in advanced economies in the 1990s, it has enormous potential also for developing countries (Evenson 2002). How quickly and comprehensively that potential is realized, however, depends heavily on consumer attitudes towards GMOs and associated policy responses, especially in Western Europe which is the destination of many developing countries farm exports.

Current debates about the new agricultural biotechnologies that are generating GMOs appear to reveal substantially different perceptions of the associated risks and benefits among consumers, ethicists, policymakers and even some scientists. Genetically modified crop varieties offer farmers desirable agronomic and farmer health benefits such as resistance to insect pests or tolerance to herbicides used to control weeds. In the near future GM products may also have attributes desired by consumers such as vitamin enrichment (e.g., golden rice).

However, serious concerns are being voiced about both the longer-term environmental impact of cultivating GM crops and the safety of foods containing GMOs. Scepticism toward genetic engineering has been particularly noticeable in Western Europe, and the development and use of genetically engineered products there and elsewhere has been stunted as a result. In contrast, farmers in North America and several large developing countries such as Argentina and China have adopted genetically modified crops as they have become available, and citizens there have generally accepted that on-going development as if GM-inclusive and 
GM-free products are the same.

The wide range of perceptions of the desirability of this new biotechnology, together with the extreme (and far from optimal) policy responses to date by the two major players (the EU and US), complicates the analysis of the economic effects of this agricultural research. But four other factors add further complications. First, since the first two major crops for which GM varieties have been developed - maize and soybean - are widely traded internationally, a global economic model is needed to capture the international spillovers (Alston 2002). Second, since those two crops are key inputs into livestock production and processed food, a multimarket model is needed to capture those interactions (Alston 1991). Third, since those and other crops being genetically modified by scientists are a non-trivial part of household earnings and spending in many poor countries, an economy-wide rather than just partial-equilibrium perspective is required. And fourth, since those product markets are subject to major pricesupport policies in Europe and elsewhere - which are under great pressure to be reformed - the impacts of existing protectionist policy measures on the benefits of the research, and of trade policy reactions to it, need to be taken into account (Alston, Edwards and Freebairn 1988). Given these complications, and despite the fact that most economic analyses of agricultural research have been partial equilibrium in nature, ${ }^{1}$ a more appropriate tool for analysing the production, trade and welfare effects of GM crop technology adoption is a global, computable general equilibrium model. This is the approach to be taken here, using the wellreceived GTAP model (described in detail in Hertel 1997).

Specifically, the effects of an assumed degree of productivity growth in the maize and soybean sectors in selected non-European countries are explored. The paper first summarizes the authors' earlier analysis which focuses on effects on world production and trade patterns and on national economic welfare of selected (non-European) countries adopting genetically modified (GM) crops without and then with Western Europe choosing to ban imports of those products from countries adopting GM technology. That ban is shown to have non-trivial economic implications for both developed and developing country agricultural-exporters. We then compare those results with what they would be in the absence of Western Europe's distortionary agricultural policies, to examine the extent to which those

\footnotetext{
${ }^{1}$ In their excellent, in-depth survey of methodologies for evaluating agricultural research, Alston, Norton and Pardey (1995) devote less than two of their 600 pages to general equilibrium analysis.
} 
price-support policies affect the various regions' welfare gains from the new biotechnology. In their survey of partial equilibrium analyses of the effects of distortionary policies on research benefits, Alston Edwards and Freebairn (1988) conclude that, while such policies typically have little impact on the global level of benefits, they do influence the distribution of those benefits within and between countries. The present study shows that can also true when general equilibrium analysis is used.

\section{Estimating Economic Effects of GMO Adoption and of Policy Reactions ${ }^{2}$}

This section examines empirically the production, trade and welfare effects of GM crop adoption by selected regions, first without and then with a specific policy response in Western Europe, namely a ban on imports of maize and soybean from GM-adopting countries. This is done using an applied analytical framework involving a global economy-wide model and database known as GTAP (Global Trade Analysis Project). ${ }^{3}$ Being a general equilibrium model, GTAP describes both the vertical and horizontal linkages between all product markets both within the model's individual countries and regions as well as between countries and regions via their bilateral trade flows. The database used for this application reflects the global economic structures and trade flows of 1995 (GTAP database Version 4 - see McDougall et al. 1998) and has been aggregated to highlight the main participating regions and the sectors affected by the GMO debate.

Currently it is primarily maize and soybean that are benefiting most from GMO food technology. Hence the scenarios analysed here assume that GM-driven productivity growth occurs only in the following GTAP sectors: cereal grains (excluding wheat and rice) and oilseeds. Detailed empirical information about the impact of GMO technology in terms of reduced chemical use, higher yields and other agronomic improvements is at this stage quite limited (see e.g. OECD (1999) and Nelson et al. (1999)). Available empirical evidence (e.g. USDA 1999

\footnotetext{
${ }^{2}$ This section draws on Nielsen and Anderson (2001).

${ }^{3}$ The GTAP (Global Trade Analysis Project) model is a multi-regional, static, applied general equilibrium model based on neo-classical microeconomic theory. See Hertel (1997) for comprehensive documentation.
} 
and James 2003) does, however, suggest that cultivating GM crops has general cost-reducing effects. The scenarios analysed here are therefore based on a simplifying assumption that the effect of adopting GM crops can be captured by a Hicks-neutral technology shift, i.e. a uniform reduction in all inputs to obtain the same level of production. For present purposes the GM-adopting sectors are assumed to experience a one-off increase in total factor productivity of 5\%, thus lowering the supply price of the GM crop ${ }^{4}$. Assuming sufficiently elastic demand conditions, the cost-reducing technology will lead to increased production and higher returns to the factors of production employed in the GM-adopting sector. Labour, capital and land consequently will be drawn into the affected sector. As suppliers of inputs and buyers of agricultural products, other sectors will also be affected by the use of genetic engineering in GM-potential sectors through vertical linkages. Input suppliers will initially experience lower demand because the production process in the GM sector has become more efficient. To the extent that the production of GM crops increases, however, the demand for inputs by producers of those crops may actually rise despite the input-reducing technology. Demanders of primary agricultural products such as grains for livestock feed will benefit from lower prices, which in turn will affect the market competitiveness of livestock products.

The widespread adoption of GM varieties in certain regions will affect international trade flows depending on how traded the crop in question is and whether or not this trade is restricted specifically because of the GMOs involved. To the extent that trade is not further restricted and not currently subject to binding tariff quotas, ${ }^{5}$ world market prices for these products will have a tendency to decline and thus benefit regions that are net importers of these products. For exporters, the lower price may or may not boost their trade volume, depending on price elasticities in the various markets. Welfare in the exporting countries would go down for nonadopters but could also go down for some adopters if the adverse terms of trade change were to be sufficiently strong. Hence the need for empirical analysis.

Two scenarios are considered in this section. The first is a base case with no

\footnotetext{
${ }^{4}$ Due to the absence of sufficiently detailed empirical data on the agronomic and hence economic impact of cultivating GM crops, the 5\% productivity shock applied here represents an average shock (over both commodities and regions). Changing this shock (e.g. doubling it to 10\%) generates near-linear changes (i.e. roughly a doubling) in the effects on prices and quantities.

${ }^{5}$ For a similar analysis to the present one but where the EUs Common Agricultural Policy is assumed to have binding import quotas, see van Meijl and van Tongeren (2002).
} 
policy or consumer reactions to GMOs, while the second imposes on this base case a ban on imports of the two products from GM-adopting countries. The base scenario examines the implications of widespread adoption of GM maize and soybeans in a number of current and potential biotech front-runner countries: North America including Mexico, the Southern Cone region of Latin America, India, China, East Asia's other lower-income countries, and South Africa. The countries of Western Europe and elsewhere are assumed to refrain completely from the use of GM crops in their production systems. For the EU this may be interpreted as an extension of the de facto moratorium that has been in place there since June 1999, awaiting the adoption of tighter laws on GMOs. Most notably among the developing countries, SubSaharan Africa is assumed to be unable to take advantage of the new technology. As mentioned above, the technology change is assumed to imply a 5\% productivity growth in the adopting sectors. Moreover, consumers are assumed not to be concerned about the introduction of GM crops in the agri-food system, and hence genetically modified and conventional crops are produced side-by-side and traded in one comingled market. There are no restrictions on trade with genetically modified products in this first scenario.

In the second scenario, Western Europe not only continues to refrain from using GM crops in its own domestic production systems, but the region is also assumed to reject imports of oilseeds and coarse grains from GM-adopting regions. It is assumed that the labelling requirements of the Biosafety Protocol enable Western European importers to identify such shipments and that basically all oilseed and coarse grain exports from GM-adopting regions will be labelled "may contain GMOs". Hence the distinction between GM and GM-free products is simplified to one that relates directly to the country of origin ${ }^{6}$. This import ban scenario reflects the most extreme application of the precautionary principle within the framework of the Biosafety Protocol.

Scenario 1: Selected non-European regions adopt GM coarse grains and oilseeds

Table 1 reports the results of the first experiment for selected regions, with Western Europe and Sub-Saharan Africa as non-adopters and the other reported

\footnotetext{
${ }^{6} \mathrm{By}$ distinguishing between GMO-inclusive and GMO-free products by country of origin, one concern may be that GM-adopting regions channel their exports to the country or region imposing the import ban (here Western Europe) through third countries that are indifferent as to the content of GMOs and that do not adopt GM technology in their own production systems. The possibility of such transshipments is abstracted from in this analysis.
} 
regions (North America, Southern Cone, China and India) as adopters of GM coarse grains and oilseeds. A 5\% reduction in overall production costs in these sectors leads to increases in coarse grains production of between $0.4 \%$ and $2.1 \%$, and increases in oilseed production of between $1.1 \%$ and $4.6 \%$ in the GMadopting regions. The production responses are generally larger for oilseeds as

Table 1. Scenario 1: Effects of selected regions ${ }^{\mathrm{a}}$ adopting GM maize and soybean

(a) Effects on production, domestic prices and trade (percentage changes)

\begin{tabular}{|c|c|c|c|c|c|c|c|}
\hline & $\begin{array}{c}\text { North } \\
\text { America }\end{array}$ & $\begin{array}{l}\text { Southern } \\
\text { Cone }\end{array}$ & China & India & $\begin{array}{l}\text { Western } \\
\text { Europe }\end{array}$ & $\begin{array}{c}\text { Sub-Saharan } \\
\text { Africa }\end{array}$ & $\begin{array}{c}\text { Australia } \\
\text { and New } \\
\text { Zealand }\end{array}$ \\
\hline \multicolumn{8}{|l|}{ Production } \\
\hline Coarse grain & 2.1 & 1.6 & 1.0 & 0.4 & -4.5 & -2.3 & -5.0 \\
\hline Oilseeds & 3.6 & 4.6 & 1.8 & 1.1 & -11.2 & -1.3 & -3.4 \\
\hline Livestock & 0.8 & -0.0 & 0.1 & 0.4 & -0.2 & -0.1 & -0.8 \\
\hline Meat \& dairy & 0.5 & 0.0 & 0.1 & 1.3 & -0.1 & -0.1 & -0.6 \\
\hline Veg. Oils, fats & 1.1 & 4.5 & 1.4 & 0.0 & -0.9 & -1.2 & -2.1 \\
\hline Other foods & 0.2 & 0.1 & 0.4 & 1.5 & -0.1 & 0.0 & -0.3 \\
\hline \multicolumn{8}{|l|}{ Market prices } \\
\hline Coarse grain & -5.5 & -5.5 & -5.6 & -6.7 & -0.5 & -0.4 & -0.8 \\
\hline Oilseeds & -5.5 & -5.3 & -5.6 & -6.5 & -1.2 & -0.3 & -0.7 \\
\hline Livestock & -1.8 & -0.3 & -0.4 & -1.4 & -0.3 & -0.3 & -0.4 \\
\hline Meat \& dairy & -1.0 & -0.2 & -0.3 & -1.0 & -0.2 & -0.2 & -0.2 \\
\hline Veg. Oils, fats & -2.4 & -3.1 & -2.6 & -1.0 & -0.5 & -0.2 & -0.3 \\
\hline Other foods & -0.3 & -0.2 & -0.5 & -1.0 & -0.1 & -0.2 & -0.1 \\
\hline \multicolumn{8}{|l|}{$\overline{\text { Exports }^{b}}$} \\
\hline Coarse grain & 8.5 & 13.3 & 16.8 & 37.3 & -11.5 & -20 & -26.8 \\
\hline Oilseeds & 8.5 & 10.5 & 8.2 & 21.5 & -20.5 & -26.5 & -28.4 \\
\hline Livestock & 8.9 & -2.0 & -3.3 & 9.4 & -1.1 & -1.5 & -1.5 \\
\hline Meat \& dairy & 4.8 & -0.9 & -0.9 & 5.8 & -0.5 & -0.2 & -1.3 \\
\hline Veg. oils, fats & 5.8 & 14.3 & 5.6 & -3.8 & -4.9 & -5.3 & -10.9 \\
\hline Other foods & 0.2 & 0.1 & 1.6 & 7.6 & -0.6 & 0.1 & -1.3 \\
\hline \multicolumn{8}{|l|}{ Imports $^{b}$} \\
\hline Coarse grain & -1.6 & -4.6 & -4.2 & -20.5 & 0.1 & 11.3 & 11.3 \\
\hline Oilseeds & -2.6 & -9.2 & -1.6 & -8.6 & 2.5 & 16.5 & 13.7 \\
\hline Livestock & -2.1 & 1.3 & 0.9 & -5.2 & 0.2 & 0.5 & 0.5 \\
\hline Meat \& dairy & -1.9 & 0.2 & 0.8 & -1.7 & -0.0 & 0.1 & 0.0 \\
\hline Veg. oils, fats & -3.7 & -3.6 & -1.7 & 3.1 & 1.3 & 3.4 & 3.7 \\
\hline Other foods & 0 & -0.1 & -0.6 & -3.1 & 0.1 & -0.1 & 0.4 \\
\hline
\end{tabular}


(b) Effects on regional economic welfare

\begin{tabular}{|c|c|c|c|c|}
\hline & \multirow{2}{*}{$\begin{array}{c}\text { Equivalent } \\
\text { Variation }(\mathrm{EV}) \\
\text { (US\$ million pa) }\end{array}$} & \multicolumn{3}{|c|}{$\begin{array}{l}\text { Decomposition of welfare results, } \\
\text { contribution of (US\$ million): }\end{array}$} \\
\hline & & $\begin{array}{c}\text { Allocative } \\
\text { efficiency effects }\end{array}$ & $\begin{array}{l}\text { Terms of } \\
\text { trade effects }\end{array}$ & $\begin{array}{c}\text { Technical } \\
\text { change effects }\end{array}$ \\
\hline North America & 2,624 & -137 & $-1,008$ & 3,746 \\
\hline Southern Cone & 826 & 120 & -223 & 923 \\
\hline China & 839 & 113 & 66 & 672 \\
\hline India & 1,265 & 182 & -9 & 1,094 \\
\hline Western Europe & 2,010 & 1,755 & 253 & 0 \\
\hline Sub-Saharan Africa & -9 & -2 & -9 & 0 \\
\hline Aust/New Zealand & -70 & 3 & -71 & 0 \\
\hline Japan \&Asian NIEs & 1,256 & 551 & 712 & 0 \\
\hline Other dev/transition & 1,120 & 171 & 289 & 673 \\
\hline WORLD & 9,859 & 2,756 & $\mathbf{0}$ & 7,108 \\
\hline
\end{tabular}

${ }^{\mathrm{a}}$ North America, Mexico, Southern Cone, China, Rest of East Asia, India, and South Africa. ${ }^{b}$ Includes intra-regional trade.

Source: Nielsen and Anderson's (2001) GTAP model results.

compared with coarse grains. This is because a larger share of oilseed production as compared with coarse grains production is destined for export markets in all the reported regions, and hence oilseed production is not limited to the same extent by domestic demand, which is less price-elastic. Increased oilseed production leads to lower market prices and hence cheaper costs of production in the vegetable oils and fats sectors, expanding output there. This expansion is particularly marked in the Southern Cone region of South America where no less than one-fourth of this production is sold on foreign markets, thereby allowing for a larger production response to the reduced costs of production in this sector. In North America coarse grains are also used as livestock feed, and hence the lower feed prices lead to an expansion of the livestock and meat processing sectors.

Due to the very large world market shares of oilseeds from North and South America and coarse grains from North America, the increased supply from these regions causes world prices for coarse grains and oilseeds to decline by $4.0 \%$ and $4.5 \%$, respectively. As a consequence of the more intense competition from abroad, production of coarse grains and oilseeds declines in the non-adopting regions. This is particularly so in Western Europe, a major net importer of oilseeds, of which $47 \%$ initially comes from North America. Coarse grain imports into Western Europe increase only slightly $(0.1 \%)$, but the increased competition 
and lower price are enough to entail a $4.5 \%$ decline in Western European production. In the developing countries too, production of coarse grains and oilseeds is reduced slightly. The changes in India, however, are relatively small compared with e.g. China and the Southern Cone region. This is explained by the domestic market orientation of these sales. As a consequence, the relatively small production increase causes rather substantial declines in market prices for these products, which in turn benefits the other agricultural sectors through vertical linkages. For example, $67 \%$ of intermediate demand for coarse grains and $37 \%$ of intermediate demand for oilseeds in India stems from the livestock sector.

The economic welfare effects of this productivity shock are difficult to capture fully. One reason is that this technology may increase or decrease the gap between the private and social marginal costs of production. Some attributes of GM crops lead to less spraying, for example, while other attributes may impose negative environmental externalities (e.g., cross-pollination with neighbouring organic crops). Until more-precise information becomes available, we simply assume the gap between the private and social marginal costs of production remains unchanged. A second reason is that consumers may not consider the GM-free and GM-included maize or soybean products to be identical. Yet the premium for GM-free or discount for GM-inclusive products has been rather small to date, so we ignore this possibility. With those two assumptions, it is possible to use the standard equivalent variation in income calculus in the GTAP model to estimate the gross economic welfare effects on each region represented in the model (see Hertel 1997), from which the costs of research and adoption should be subtracted with appropriate discounting to account for the delay between research investments and their impacts.

Global economic welfare (so measured) is boosted in this first scenario by US\$9.9 billion per year, two-thirds of which is enjoyed by the adopting regions (Table 1(b)). It is noteworthy that all regions (both adopting and non-adopting) gain in terms of economic welfare except Sub-Saharan Africa. The welfare decomposition in Table 1(b) shows that most of this gain stems directly from the technology boost. The net-exporting GM-adopters experience worsened terms of trade due to increased competition on world markets, but this adverse welfare effect is outweighed by the positive effect of the technological boost. Western Europe gains from the productivity increase in the other regions only in part because of cheaper imports; mostly it gains because increased competition from abroad shifts domestic resources out of relatively highly assisted segments of EU 
agriculture. The group of other high-income countries, among which are the Asian nations that are relatively large net importers of the GM-potential crops, benefits equally from lower import prices and a more efficient use of resources in domestic production. $^{7}$

Scenario 2: Western Europe bans the imports of GM coarse grains and oilseeds

A Western European ban on the imports of genetically modified coarse grains and oilseeds would change the situation rather dramatically, especially for the oilseed sector in North America, which is initially highly dependent on the EU market. The result of the European ban is not only a decline in total North American oilseed exports by almost $30 \%$, but also a production decline of $10 \%$, pulling resources such as land out of this sector (Table 2). For coarse grains, by contrast, only $18 \%$ of North American production is exported and just $8 \%$ of those exports are destined for Western Europe. Therefore the ban does not affect North American production and exports of coarse grains to the same extent as for oilseeds, although the downward pressure on the international price of maize nonetheless dampens the production-enhancing effect of the technological boost significantly. Similar effects are evident in the other GM adopting regions, except for India - once again because its production of these particular crops is largely unaffected by world market developments.

For Sub-Saharan Africa, which by assumption is unable to adopt the new GM technology, access to the Western European markets when other competitors are excluded expands. Oilseed exports from this region rise dramatically, by enough to increase domestic production by $4 \%$. Western Europe increases its own production of oilseeds, however, so the aggregate increase in its oilseed imports amounts to less than $1 \%$. Its production of coarse grains also increases, but proportionately not as much because of an initial high degree of self-sufficiency. The shift from imported oilseeds and coarse grains to domestically produced products has implications further downstream. Given an imperfect degree of

${ }^{7}$ In the present analysis no attempt has been made to allocate national welfare gains among household groups. That could be done simply by using the GTAP models estimates of changes in product and factor prices and information on different households shares of expenditure on the various products and of income from the various factors (different types of labour, land, and other forms of capital). Such an approach is more satisfactory than the standard partial equilibrium distinction between producers, consumers and taxpayers (see, e.g., Alston, Edwards and Freebairn 1988) since each household has an interest in at least two of those outcomes. This is especially true in poor countries where the vast majority of households include agricultural producers but they have widely varying ownership of the various factors of production and degrees of self-sufficiency in food production. 
substitution in production between domestic and imported intermediate inputs, the higher prices on domestically produced grains and oilseeds mean that livestock feed is slightly more expensive (half of intermediate demand for coarse grains in Western Europe stems from the livestock sector). Inputs to the other food processing industries, particularly the vegetable oils and fats sector, also are more

Table 2. Scenario 2: Effects of selected regions ${ }^{\mathrm{a}}$ adopting GM maize and soybean plus WE bans GM imports

(a) Effects on production, domestic prices and trade (percentage changes)

\begin{tabular}{|c|c|c|c|c|c|c|c|}
\hline & $\begin{array}{c}\text { North } \\
\text { America }\end{array}$ & $\begin{array}{l}\text { Southern } \\
\text { Cone }\end{array}$ & China & India & $\begin{array}{l}\text { Western } \\
\text { Europe }\end{array}$ & $\begin{array}{c}\text { Sub-Saharan } \\
\text { Africa }\end{array}$ & $\begin{array}{l}\text { Australia } \\
\text { and New } \\
\text { Zealand }\end{array}$ \\
\hline \multicolumn{8}{|l|}{ Production } \\
\hline Cereal grain & 0.9 & 0.0 & 0.8 & 0.4 & 5.3 & -2.2 & -5.2 \\
\hline Oilseeds & -10.2 & -3.6 & -0.8 & 0.8 & 66.4 & 4.4 & -1.3 \\
\hline Livestock & 1.2 & 0.3 & 0.2 & 0.4 & -0.8 & 0.0 & -0.4 \\
\hline Meat \& dairy & 0.8 & 0.3 & 0.2 & 1.4 & -0.5 & -0.0 & -0.5 \\
\hline Veg.oils,fats & 2.4 & 8.1 & 1.6 & 0.1 & -3.4 & 0.0 & -2.1 \\
\hline Other foods & 0.3 & 0.4 & 0.5 & 1.6 & -0.5 & -0.1 & -0.4 \\
\hline \multicolumn{8}{|l|}{ Market prices } \\
\hline Cereal grain & -6.2 & -6.0 & -5.6 & -6.7 & 0.8 & -0.0 & -0.7 \\
\hline Oilseeds & -7.4 & -6.8 & -6.0 & -6.5 & 5.8 & 0.4 & -0.4 \\
\hline Livestock & -2.2 & -0.7 & -0.4 & -1.4 & 0.5 & 0.1 & -0.3 \\
\hline Meat \& dairy & -1.3 & -0.4 & -0.3 & -1.0 & 0.3 & 0.1 & -0.2 \\
\hline Veg.oils,fats & -3.3 & -4.0 & -2.7 & -1.0 & 2.0 & 0.0 & -0.2 \\
\hline Other foods & -0.4 & -0.3 & -0.5 & -1.0 & 0.1 & 0.0 & -0.1 \\
\hline \multicolumn{8}{|l|}{ Exports $^{b}$} \\
\hline Cereal grain & 0.3 & -2.9 & 5.0 & 23.4 & 15.9 & -13.1 & -27.1 \\
\hline Oilseeds & -28.8 & -69.2 & -18.4 & -8.7 & 167.2 & 105.0 & 3.8 \\
\hline Livestock & 13.7 & 4.0 & -1.4 & 12.6 & -3.8 & -1.8 & -0.4 \\
\hline Meat \& dairy & 7.5 & 2.1 & 0.1 & 7.1 & -1.4 & 0.3 & -1.2 \\
\hline Veg.oils,fats & 14.4 & 26.2 & 7.0 & 1.3 & -15.0 & 5.8 & -12.1 \\
\hline Other foods & 1.5 & 1.9 & 2.0 & 8.0 & -1.4 & -0.6 & -1.4 \\
\hline \multicolumn{8}{|l|}{ Imports $^{b}$} \\
\hline Cereal grain & -1.9 & -5.3 & -2.8 & -20 & 3.3 & 13.4 & 13.4 \\
\hline Oilseeds & -5.6 & -21.9 & 3.0 & -3.7 & 0.6 & 22.5 & 18.6 \\
\hline Livestock & -3.2 & 0.1 & 0.1 & -5.9 & 0.9 & 0.5 & 0.7 \\
\hline Meat \& dairy & -2.8 & -0.5 & 0.8 & -1.8 & -0.2 & -0.0 & -0.2 \\
\hline Veg.oils,fats & -7.7 & -5.5 & -1.7 & 4.0 & 5.5 & 2.4 & 2.6 \\
\hline Other foods & -0.6 & -0.6 & -0.8 & -2.8 & 0.1 & 0.2 & 0.3 \\
\hline
\end{tabular}


(b) Effects on regional economic welfare

\begin{tabular}{lrccc}
\hline & \multicolumn{2}{c}{$\begin{array}{c}\text { Equivalent } \\
\text { Variation (EV) }\end{array}$} & \multicolumn{3}{c}{ Decomposition of welfare results (US\$ million pa): } \\
\cline { 3 - 5 } & (US\$ million pa) & $\begin{array}{c}\text { Allocative } \\
\text { efficiency effects }\end{array}$ & $\begin{array}{c}\text { Terms of } \\
\text { trade effects }\end{array}$ & $\begin{array}{c}\text { Technical } \\
\text { change effects }\end{array}$ \\
\hline North America & 2,299 & 27 & $-1,372$ & 3,641 \\
Southern Cone & 663 & 71 & -303 & 893 \\
China & 804 & 74 & 70 & 669 \\
India & 1,277 & 190 & -3 & 1,092 \\
Western Europe & $-4,334$ & $-4,601$ & 257 & 0 \\
Sub-Saharan Africa & 42 & 5 & 38 & 0 \\
Aust/New Zealand & -52 & -1 & -49 & 0 \\
Japan \&Asian NIEs & 1,423 & 593 & 831 & 0 \\
Other dev/transition & 1,296 & 101 & 531 & 672 \\
\hline WORLD & $\mathbf{3 , 4 1 9}$ & $\mathbf{- 3 , 5 4 1}$ & $\mathbf{0}$ & $\mathbf{6 , 9 6 6}$ \\
\hline
\end{tabular}

${ }^{\mathrm{a} N o r t h}$ America, Mexico, Southern Cone, China, Rest of East Asia, India, and South Africa. ${ }^{\text {bncludes }}$ intra-regional trade. Source: As for Table 1.

expensive. As a consequence, production in these downstream sectors declines and competing imports increase.

Aggregate economic welfare implications of this scenario as compared with scenario 1 are substantially different. Western Europe now experiences a decline in aggregate welfare of US $\$ 4.3$ billion per year instead of a boost of $\$ 2.0$ billion (compare Tables 2(b) and 1(b)). Taking a closer look at the decomposition of the welfare changes reveals that adverse allocative efficiency effects explain the decline. Most significantly, resources are forced into producing oilseeds, of which a substantial amount was previously imported. Consumer welfare in Western Europe is reduced in this scenario because, given that those consumers are assumed to be indifferent between GM-inclusive and GM-free crops, the import ban restricts them from benefiting from lower international prices. ${ }^{8}$

The key exporters of the GM products, North America, Southern Cone and China, all show a smaller gain in welfare in this as compared with the scenario in which there is no EU response. Net importers of corn and soybean (e.g. 'Other high-income' which is mostly East Asia), by contrast, are slightly better off in this than the first scenario. Meanwhile, the countries in Sub-Saharan Africa are affected in a slight positive instead of slight negative way, gaining from better

${ }^{8}$ Of course the welfare loss reported above would be less in so far as Western Europeans value a ban on GM products in their domestic markets. 
terms of trade. In particular a higher price is obtained for their oilseed exports to Western European markets in this as compared with the first scenario.

Two-thirds of the global gains from the new GM technology as measured in scenario 1 are eroded by the import ban imposed by Western Europe: they fall from $\$ 9.9$ billion per year to just $\$ 3.4$ billion (assuming as before that consumers are indifferent between GM-free and GM-inclusive foods and there is no net change in the extent of externalities). Almost the entire erosion in economic welfare is borne in Western Europe, with the small residual borne by the net-exporting adopters (mainly North America and the Southern Cone region). Since the non-adopting regions outside Europe generally purchase most of their imported coarse grains and oilseeds from North America, they benefit even more from lower import prices: their welfare is estimated to be greater by almost one-fifth in the case of a Western European import ban as compared with no European reaction.

Our earlier analysis (Nielsen and Anderson 2001) includes a third scenario that assumes, as an alternative to an import ban, that Western European consumers who have a strong bias against genetically modified crops can express their preferences through market mechanisms rather than through a governmentimplemented import ban. This has a much less damaging effect on production in the GM-adopting countries. In particular, that earlier study analyses the impact of a partial shift in Western European preferences away from imported coarse grains and oilseeds from GM-producing countries and in favour of domestically produced crops. The estimated decline in economic welfare that Western Europe would experience if it banned coarse grain and oilseed imports is changed to a slight gain in this scenario (although recall that scenario 2 assumes consumers are indifferent to whether a food contains GMOs). The dramatic worsening of resource allocative efficiency in scenario 2 is changed to a slight improvement in this one, because production in the lightly assisted oilseeds sector increases and production in all other (more heavily distorted) agri-food sectors in Western Europe declines. ${ }^{9}$

\footnotetext{
${ }^{9}$ Anderson, Nielsen, Robinson and Thierfelder (2001) go further and analyse the effects of different degrees of consumer substitutability between GM-free and GM-inclusive products when those products are segmented in the marketplace. This latter approach is also adopted by Stone, Mastysek and Dolling (2002).
} 


\section{How different would the welfare effects of GMO adoption be in the absence of agricultural protection in Western Europe?}

The above results take as given the agricultural protection policies currently in place in Western Europe. Obviously the location of global food production would be different without that protectionism, which raises the question as to how much impact current policies are having on the gains from GM research. Alston, Edwards and Freebairn (1988) demonstrate using partial equilibrium analysis that the impact depends on numerous variables and can be positive or negative for different participants but in aggregate is likely to be small. For the case in hand, in the absence of Western Europe's protectionism the GM-adopting countries would have a larger share of global crop production, which would boost the global gains from their adoption of GM research. But without its protectionism the crop mix would be different in Western Europe, in which case a ban on imports of GM products may be less costly than with current policies still in place. That lower cost would offset the greater welfare gains from GM crop production elsewhere.

As an empirical test, we re-ran the above two simulations but in doing so we also removed all forms of protection to primary agricultural industries in Western Europe. The welfare results are reported in Table 3. The global welfare effects are about $\$ 15$ billion per year higher in this second set of scenarios where GMO adoption is accompanied by the removal of current price-distorting policies in Western Europe. That $\$ 15$ billion represents the magnitude of the annual welfare cost of those price-distorting policies.

Of more interest here are the differences between the welfare effects of GMO adoption without and with an import ban by Western Europe in this second situation, summarized in Table 3, as compared with the situation summarized in Tables 1 and 2. Those differences are reported in Table 4. What they suggest is that, as predicted by Alston, Edwards and Freebairn (1988), the current protectionist policies of Western Europe are having little impact on the difference in global gains from GM research as simulated here. In fact the reduction in the global welfare gains from GMO adoption that a European import ban would impose would be slightly smaller in the absence of Europe's current farm protection policies than in their presence ( $\$ 5.1$ instead of $\$ 6.4$ billion per year). But, also as predicted by Alston, Edwards and Freebairn (1988), the distribution of that difference is not even. Without current protectionism, a European import ban would hurt GM-adopting countries by $\$ 1$ billion per year less, but would help non- 
Table 3. Economic welfare effects of selected non-European regions adopting GM coarse grains and oilseeds and agricultural protection in Western Europe removed, without and with a Western European ban on imports from GM regions

(a) without a Western European ban on imports from GM regions

\begin{tabular}{lcccr}
\hline & $\begin{array}{c}\text { Equivalent } \\
\text { Variation (EV) }\end{array}$ & \multicolumn{2}{c}{$\begin{array}{c}\text { Decomposition of welfare results, } \\
\text { contribution of (US\$ million): }\end{array}$} \\
\cline { 3 - 5 } & (US\$ million pa) & $\begin{array}{c}\text { Allocative } \\
\text { efficiency effects }\end{array}$ & $\begin{array}{c}\text { Terms of } \\
\text { trade effects }\end{array}$ & $\begin{array}{c}\text { Technical } \\
\text { change effects }\end{array}$ \\
\hline North America & 4,359 & $-2,032$ & 2,280 & 4,056 \\
Southern Cone & 1,775 & 400 & 360 & 985 \\
China & 719 & 82 & -37 & 691 \\
India & 1,225 & 87 & 44 & 1,100 \\
Western Europe & 17,896 & 22,318 & $-4,539$ & 0 \\
Sub-Saharan Africa & 203 & 3 & 211 & 0 \\
Australia and NZ & 427 & -42 & 464 & 0 \\
Japan \& Asian NIEs & $-2,180$ & $-1,443$ & -611 & 0 \\
Other developing and & 974 & $-1,474$ & 1,782 & 0 \\
transition econs. & & $\mathbf{1 7 , 9 5 6}$ & $\mathbf{0}$ & $\mathbf{6 , 8 3 2}$ \\
\hline WORLD & $\mathbf{2 5 , 3 9 8}$ & & & 0
\end{tabular}

(b) with a Western European ban on imports from GM regions

\begin{tabular}{lcccr}
\hline & $\begin{array}{c}\text { Equivalent } \\
\text { Variation (EV) }\end{array}$ & \multicolumn{2}{c}{$\begin{array}{c}\text { Decomposition of welfare results, } \\
\text { contribution of (US\$ million): }\end{array}$} \\
\cline { 3 - 5 } & (US\$ million pa) & $\begin{array}{c}\text { Allocative } \\
\text { efficiency effects }\end{array}$ & $\begin{array}{c}\text { Terms of } \\
\text { trade effects }\end{array}$ & $\begin{array}{c}\text { Technical } \\
\text { change effects }\end{array}$ \\
\hline North America & 3,138 & $-1,816$ & 1,153 & 3,771 \\
Southern Cone & 1,425 & 349 & 135 & 915 \\
China & 700 & 44 & -9 & 682 \\
India & 1,252 & 104 & 56 & 1,097 \\
Western Europe & 11,118 & 16,970 & -5985 & 0 \\
Sub-Saharan Africa & 789 & 29 & 789 & 0 \\
Australia and NZ & 505 & -39 & 537 & 0 \\
Japan \& Asian NIEs & $-1,536$ & $-1,224$ & -187 & 0 \\
Other developing and & 2,915 & $-1,218$ & 3,511 & 0 \\
transition econs. & & $\mathbf{1 3 , 1 9 9}$ & $\mathbf{0}$ & $\mathbf{6 , 4 6 5}$ \\
\hline WORLD & $\mathbf{2 0 , 3 0 6}$ & & & \\
\hline
\end{tabular}

Source: Authors' GTAP model results.

adopters outside of Western Europe by $\$ 2.8$ billion less. Furthermore, current protectionism is affecting very little the bans impact on the indirect gain Western Europe enjoys from adoption elsewhere of the new biotechnology. As the 
Table 4. Differences between economic welfare effects of selected non-European regions adopting GM coarse grains and oilseeds with a Western European ban on imports from GM regions vs. no ban (i.e., the loss associated with the ban)

(i) without agricultural protection in Western Europe removed

Equivalent Variation Decomposition of welfare results,

(EV)

\begin{tabular}{lcccc} 
& (US\$ million pa) & $\begin{array}{c}\text { Allocative } \\
\text { efficiency effects }\end{array}$ & $\begin{array}{c}\text { Terms of } \\
\text { trade effects }\end{array}$ & $\begin{array}{c}\text { Technical } \\
\text { change effects }\end{array}$ \\
\hline GM adopters & -511 & 84 & -434 & -142 \\
Western Europe & $-6,344$ & $-6,356$ & 4 & 0 \\
Other non-adopters & 415 & -25 & 430 & 0 \\
\hline WORLD & $\mathbf{- 6 , 4 4 0}$ & $\mathbf{- 6 , 2 9 7}$ & $\mathbf{0}$ & $\mathbf{- 1 4 2}$ \\
\hline
\end{tabular}

(ii) with agricultural protection in Western Europe removed

\begin{tabular}{|c|c|c|c|c|}
\hline & \multirow{2}{*}{$\begin{array}{c}\text { Equivalent Variation } \\
\qquad(\mathrm{EV}) \\
\text { (US\$ million pa) }\end{array}$} & \multicolumn{3}{|c|}{$\begin{array}{l}\text { Decomposition of welfare results, } \\
\text { contribution of (US\$ million): }\end{array}$} \\
\hline & & $\begin{array}{c}\text { Allocative } \\
\text { efficiency effects }\end{array}$ & $\begin{array}{l}\text { Terms of } \\
\text { trade effects }\end{array}$ & $\begin{array}{c}\text { Technical } \\
\text { change effects }\end{array}$ \\
\hline GM adopters & $-1,563$ & 144 & $-1,315$ & -367 \\
\hline Western Europe & $-6,778$ & $-5,348$ & $-1,446$ & 0 \\
\hline Other non-adopters & 3,244 & 447 & 2,761 & 0 \\
\hline WORLD & $-5,097$ & $-4,757$ & $\mathbf{0}$ & -367 \\
\hline
\end{tabular}

Source: Author's GTAP model results.

decomposition numbers in Table 4 show, most of the differences are due to the terms of trade effects.

\section{Conclusions}

The empirical analysis performed here shows that the most extreme use of European trade provisions, namely an import ban on imports of crops from GMOadopting countries, would be very costly in terms of economic welfare for the Western European region itself - a cost which governments in the region need to weigh against the perceived benefits to voters of adopting the precautionary principle in this way. Imposing a ban hinders European consumers and intermediate demanders in gaining from lower import prices, domestic production of corn and soybean is forced to rise at the expense of other production, and hence overall allocative efficiency in the region is worsened. The GM-adopting regions still enjoy welfare gains due to the dominating positive effect of the assumed productivity boost embodied in the GM crops, but those gains are reduced by the 
import ban as compared with the scenario in which GM crops are traded freely. To the extent that some developing and other countries do not adopt GM crops (by choice or otherwise) and they can verify this at the Western European borders, our results suggest it is possible they could gain in gross terms - but only slightly -from retaining access to Europe's GMO-free markets when GM-adopting countries' products are excluded. Whether they gain in net terms would depend on the cost of demonstrating compliance with European regulations. A comparison between those results and ones from the second set of simulations reveals that the gains to those developing countries from the ban would be less (as would the GM-adopting countries' loss) in the absence of Western Europe current protectionist policies.

The above analysis assumes throughout that the new technology is exogenous. This is clearly just an analytical convenience. In practice the investment in new agricultural technologies is less the greater are consumers' and environmentalists' concerns with the technology: the more those concerns are unwarranted, the more developing countries are being unnecessarily denied benefits from the biotechnology revolution. Research investments are also less the lower are prices of farm products, and agricultural protectionism lowers those prices in international markets.

The different national regulatory regimes towards GM products are bound to raise questions about their compatibility with existing WTO agreements. Indeed GMOs have considerable potential to generate trade frictions in the years ahead as WTO members argue about the extent to which the precautionary principle should be envoked (Anderson and Nielsen 2002). The above estimated welfare effects of a ban on EU imports of GM products may not seem huge, but two things need to be kept in mind. One is that the above results are based on the assumed flexibility of markets in the GTAP model, with most of the global welfare loss from an import ban being borne by the banning region. The other is that this study focuses on a small number of countries adopting GM technology for just two products, and with defensive reactions by just one (albeit the largest and most likely) region. The potential of this new biotechnology and the associated gains through trade in the decades ahead are many times greater than the above estimates, and ultimately could be huge as a percentage of incomes of poor people in developing countries. ${ }^{10}$ Hence so too are the stakes in terms of potential trade disputes, should governments respond to GMO developments in ways that upset other WTO

\footnotetext{
${ }^{10}$ On the role agricultural research can play in alleviating poverty in developing countries, see Hazell and Haddad (2001) and Ryan (2002).
} 
members.

Nonetheless, the EU or some other countries may still choose to impose import restrictions on GM products, for at least four reasons. First, the Biosafety Protocol might be interpreted by them as absolving them of their WTO obligations not to raise import barriers. Second, if domestic production of GM crops is banned in Europe, farmers there would join with GMO protesters in calling for a raising of import barriers so as to keep out lower-cost 'unfair' competition. Third, the ongoing lowering of traditional import barriers, following the Uruguay Round Agreement on Agriculture, is putting pressure on import-competing farmers to look for non-traditional ways of cutting imports. ${ }^{11}$ And fourth, the cost of banning GMO imports in Western Europe amounts to barely US\$15 per capita per year hardly a major economic impediment to a high-income region imposing an import ban.

The scope for further economic analysis of the economics of biotech research is considerable. An obvious extension of the present study is to explore the effects of developing countries' policies (which on average discriminate against agriculture) on the rewards in those countries from the adoption of new biotechnologies abroad and at home. Another extension is to identify different types of households within the GTAP model so that the within-country income distributional and poverty alleviation consequences of GMO adoption - and of policy and consumer reactions to GMO trade - can be estimated. ${ }^{12}$ Once that is done, we will be in a better position to move from normative to positive analyses and address such questions as to why policies towards GMOs are so different across countries. Arguably neither the US nor the EU policies are anywhere near optimal: the US having very few regulations even though there are uncertainties as to the environmental effects of GM crop production and the food safety consequences of GMO consumption; and the EU having the most extreme of regulations to deal with those issues. Are these differences simply a result of different consumer and

\footnotetext{
${ }^{11}$ The emergence of the concept of agriculture's so-called 'multifunctionality', and the call for trade policy and the WTO to deal with environmental and labour standards issues, can be viewed in a similar light (Anderson 1998, 2000).

${ }^{12}$ The increasing concern in both rich and poor countries about who gains and who loses from trade and economic growth has meant that the GTAP model is beginning to be used for exploring the distributional and poverty implications of trade liberalization. See, for example, the study of trade reform in China by Anderson, Huang and Ianchovichina (2004) and a global study by Hertel et al. (2002). Distributional analyses of agricultural research impacts can piggy-back on such studies once households are specified in such models
} 
environmentalist attitudes in the two regions, as suggested by many analysts (e.g., Benauer 2003)? Or are they due to different vested interests of producers, who are exerting their lobbying influence on this area of policy just as they do in the area of traditional price and trade policies? Given the scope that GMOs provide for reinstrumenting agricultural protectionism in the wake of the Uruguay Round Agreement on Agriculture and its likely extension following the on-going Doha Round of multilateral trade negotiations, this promises to be a high-payoff area for further economic research.

\section{Acknowledgements}

Revision of a paper prepared for the John L. Dillon Commemorative Day on Agricultural Research: Challenges and Economics in the New Millennium, University of New England Armidale, 20 September 2002. The authors are grateful for comments from conference participants and referees, and for financial assistance from the Australian Research Council, RIRDC and the World Bank.

Received 16 December 2002, Accepted 14 April 2004

\section{References}

Alston, J.M. (1991), 'Research Benefits in a Multimarket Setting', Review of Marketing and Agricultural Economics 59(1): 23-52, April.

Alston, J.M. (2002), 'Spillovers', Australian Journal of Agricultural and Resource Economics 46(3): 315-46, September.

Alston, J.M., G.W. Edwards and J.W. Freebairn (1988), 'Market Distortions and Benefits from Research', American Journal of Agricultural Economics 70(2): 281-88, May.

Alston, J.M., G.W. Norton and P.G. Pardey (1995), Science Under Scarcity: Principles and Practice for Agricultural Research Evaluation and Priority Setting, Ithaca: Cornell University Press.

Alston, J.M. and P.G. Pardey (1996), Making Science Pay: The Economics of Agricultural $R \& D$ Policy, Washington, D.C.: AEI Press.

Anderson, K. (1998), 'Environmental and Labor Standards: What Role for the WTO?' Ch. 8 in The WTO as an International Organization, edited by Anne O. Krueger, Chicago: University of Chicago Press.

Anderson, K. (2000), 'Agriculture's 'Multifunctionality' and the WTO', Australian Journal of Agricultural and Resource Economics 44(3): 475-94, September.

Anderson, K., J. Huang and E. Ianchovichina (2004), 'Impacts of WTO Accession on 
Chinese Agriculture and Rural Poverty', Ch. 7 in China and the World Economy: Policy and Poverty after China's Accession to the WTO, edited by D. Bhattasali, S. $\mathrm{Li}$ and W. Martin, London: Oxford University Press (forthcoming).

Anderson, K. and C.P. Nielsen (2002), 'GMOs, Food Safety and the Environment: What Role for Trade Policy and WTO?' in Tomorrow's Agriculture: Incentives, Institutions, Infrastructure and Innovations, edited by G.H. Peters and P. Pingali, Aldershot: Ashgate.

Anderson, K., C. Nielsen, S. Robinson and K. Thierfelder (2001), 'Estimating the Global Economic Effects of GMOs', Ch. 4 in The Future of Food: Biotechnology Markets and Policies in an International Setting, edited by P. Pardey, Washington, D.C.: International Food Policy Research Institute.

Bernauer, T. (2003), Genes, Trade and Regulation: The Seeds of Conflict in Food Biotechnology, Princeton: Princeton University Press.

Evenson, R.E. (2002), From the Green Revolution to the Gene Revolution', Ch. 1 in Economic and Social Issues in Agricultural Biotechnology, edited by R.E. Evenson, V. Santaniello and D. Zilberman, London: CAB International.

Hazell, P. and L. Haddad (2001), 'Agricultural Research and Poverty Reduction', IFPRI Discussion Paper 34, Washington, D.C.: International Food Policy Research Institute, August.

Hertel, T.W. (1997) (ed.), Global Trade Analysis: Modeling and Applications, Cambridge and New York: Cambridge University Press.

Hertel, T.W., P.V. Preckel, M. Ivanic and J.A.L. Cranfield (2002), 'Poverty Impacts of Multilateral Liberalization', Paper presented at the $5^{\text {th }}$ Conference on Global Economic Analysis, Taipei, 5-7 June.

James, C. (2003), Global Review of Commercialized Transgenic Crops: 2002, International Service for the Acquisition of Agri-biotech Applications, Ithaca NY, November.

Lindner, R.J. and F.G. Jarrett (1978), 'Supply Shifts and the Size of Research Benefits', American Journal of Agricultural Economics 60(1): 48-58, February.

McDougall, R.A., A. Elbehri and T.P. Truong (1998) (eds.), Global Trade, Assistance, and Protection: The GTAP 4 Data Base, Center for Global Trade Analysis, Purdue University, West Lafayette.

Nelson, G.C., T. Josling, D. Bullock, L. Unnevehr, M. Rosegrant and L. Hill (1999), The Economics and Politics of Genetically Modified Organisms: Implications for WTO 2000, Bulletin 809, College of Agricultural, Consumer and Environmental Sciences, University of Illinois at Urbana-Champaign, November.

Nielsen, C.P. and K. Anderson (2001), 'Global Market Effects of European Responses to Genetically Modified Organisms', Weltwertschaftliches Archiv 137(2): 320-46, June.

OECD (1999), Modern Biotechnology and Agricultural Markets: A Discussion of Selected Issues and the Impact on Supply and Markets, Directorate for Food, Agriculture and Fisheries. Committee for Agriculture, AGR/CA/APM/CFS/MD(2000) 2, Paris: OECD.

Ryan, J. (2002), 'Agricultural Research and Poverty Alleviation: Some International Perspec- 
tives', paper presented at the John L. Dillon Commemorative Day on Agricultural Research: Challenges and Economics in the New Millennium, University of New England, Armidale, 20 September.

Stone, S., A. Matysek and A. Dolling (2002), Modelling Possible Impacts of GM Crops on Australian Trade, Staff Research Paper, Canberra: Productivity Commission, October.

USDA (1999), 'Impact of Adopting Genetically Engineered Crops in the U.S. Preliminary Results', Economic Research Service, US Department of Agriculture. Washington, DC, 20 July.

Van Miejl, H. and F. van Tongeren (2002), 'International Diffusion of Gains from Biotechnology and the European Union's Common Agricultural Policy', Paper presented at the $5^{\text {th }}$ Conference on Global Economic Analysis, Taipei, 5-7 June. 